Egypt. Poult. Sci. Vol. (39) (II): (443-458 ) (2019)

(1905-1034)

Egyptian Poultry Science Journal

http://www.epsj.journals.ekb.eg/

ISSN: 1110-5623 (Print) - 2090-0570 (Online)

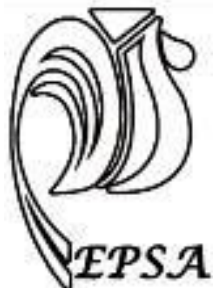

\title{
EFFECT OF MELATONIN SUPPLEMENTATION TO FREEZING EXTENDER ON POST-THAW SPERM KINETICS, ANTIOXIDANT CAPACITY AND FERTILITY TRAITS IN BUCK RABBITS
}

\author{
SH M. Dessouki ${ }^{1,2 *}$ and O. G. Sakr ${ }^{1}$
}

${ }^{1}$ Dep. of Anim.Prod., Fac. of Agric., Cairo Uni., Egypt.

${ }^{2}$ Cairo Uni. Res. Park (CURP), Fac. of Agric., Cairo Uni., Egypt.

Corresponding authors:Dr. Sherif Dessouki Email:sherifd2002@agr.cu.edu.eg

\begin{abstract}
Received: 12/05 /2019
Accepted: $17 / 06 / 2019$

ABSTRACT:This study was carried out to monitor the fertilizing ability of rabbit semen frozen in the presence of melatonin as antioxidant. Semen from 10 mature Egyptian Baladi red bucks was pooled, extended with Tris-glucose-citric extender (1:1 $\mathrm{v} / \mathrm{v})$ supplemented by three concentrations of melatonin $\left(10^{-9}, 10^{-6}\right.$ and $\left.10^{-3} \mathrm{M}\right)$ in addition to control, and finally cryopreserved at $-196^{\circ} \mathrm{C}$. After thawing, sperm kinetics, antioxidant capacity and fertility traits were evaluated. The results showed that total and progressive motility percentages were higher significantly in samples cryopreserved by melatonin $\left(10^{-6} \mathrm{M}\right)$ as compared to control group. Curvilinear and average path sperm velocities were significantly higher in melatonin groups of $10^{-9}$ and $10^{-6} \mathrm{M}$ than in the control group. Supplementation of melatonin at $10^{-9} \mathrm{M}$ and $10^{-6} \mathrm{M}$ groups decreased (P $<0.05)$ malondialdehyde activity when compared to the control one. In contrast, the total antioxidant capacity and catalase activity were significantly $(\mathrm{P}<0.05)$ elevated at concentration of $10^{-6} \mathrm{M}$ melatonin as compared to the control group. In addition, transcript abundance of NFE2L2 and SOD1 genes increased in groups supplemented with melatonin compared to the control group.

The fertility trial indicated that pregnancy rate, and the total and live born increased significantly $(\mathrm{P}<0.05)$ in rabbit does inseminated with semen of $10^{-6} \mathrm{M}$ melatonin group in compared to the control samples.

Conclusively, these results concluded that using melatonin with $10^{-6} \mathrm{M}$ level in rabbit freezing extenders could be recommended to improve semen quality and fertilizing ability of buck sperm post-thawing.
\end{abstract}

Keywords: Melatonin concentrations-sperm motility-fertility traits; bucks \& does-rabbits 


\section{INTRODUCTION}

Semen cryopreservation is known as assisted reproductive technology and is effectively used for prolonged storage and reconstitution of valued animal genetic resources. However, in vitro manipulation, during freezing process runs the risk of sperm exposure to supraphysiological concentrations of reactive oxygen species (ROS) that, in turn, reduce their post-thaw viability in different species (Kadirvel et al., 2009; Kumaresan et al., 2009; Lucio et al., 2016; Partyka et al., 2012; Sarı̈zkan et al., 2015; Viudes-De-Castro et al., 2014). The detrimental effects of ROS on sperm are mostly due to deformity, lipid peroxidation, DNA fragmentation, acrosome damage, denaturation of the enzymes and limit the ability to regulate gene expression (Gil-Guzman et al., 2001). In this context, the addition of antioxidants to semen extenders is crucial to prevent oxidative damage and maximize fertilization capacity of cryopreserved sperm (Berra and Rizzo, 2009).

Melatonin (N- actey 1-5 methoxy tryptamine) is secreted by the pineal gland in the brain and has multiple actions on different physiological and neuroendocrine systems (Awad et al., 2006). Some studies have demonstrated that melatonin has protective effects as an antioxidant because of its high efficacy as a hydroxyl radical $(\mathrm{OH} \bullet)$ scavenger (ElSokkary et al., 2003). Furthermore, melatonin has the ability to detoxify different kinds of ROS and hydrogen peroxide (Tan et al., 2002). Addition of melatonin to semen freezing extenders has shown potential antioxidant effects on sperm and improvement in sperm motility after thawing in ram (Ashrafi et al., 2011; Succu et al., 2011), boar (Jang et al.,
2010), equine (Lançoni et al., 2018), bull (Ashrafi et al., 2013), mouse (Chen et al., 2016) and human (Karimfar et al., 2015). However, further studies and better knowledge are necessary about the effects of melatonin on semen cryopreservation at cellular and molecular levels, particularly in rabbit species.

Therefore, the present study aims at investigating the effect of melatonin supplementation at different levels to the rabbit semen freezing extender on postthaw sperm motility, antioxidant biomarkers and stress-response-related genes. In addition, a fertility trial was performed to evaluate the fertilizing ability of frozen semen with melatonin concentrations after thawing.

MATERIALS AND METHODS Animals and ethical statement

Semen samples from 10 rabbit males belonging to Egyptian Baladi red breed (Khalil, 2002) were used in this experiment. All bucks were the same age (6 months) with average $3.5 \mathrm{~kg}$ body weight at the onset of the present study. All rabbits were housed in a semi-closed housing system, (Faculty of Agriculture, Cairo University, Egypt) during the study.

The males were maintained in the standard environmental status. They were exposed to light cycle of $16 \mathrm{~L} / 8 \mathrm{D}$ hours and they were provided with the commercial diet. The composition of the pellets was as following; $18.4 \% \mathrm{CP}, 3.1 \%$ ether extract, $12.7 \%$ crude fibre and 2.600 kcal DE/kg according to (NRC, 1977) and water was available with free access. The experimental procedures were approved by the Institutional Animal Care and Use Committee at Cairo University Egypt (CU-II-F-14-19) ICUAC). 
Melatonin concentrations-sperm motility-fertility traits; bucks \& does-rabbits

\section{Semen Collection and Processing}

Ejaculates were collected from the bucks twice/ week for consecutive 6 weeks with using rabbit's artificial vagina. The semen samples were immediately transferred to the lab and submerged in a water bath $\left(38.5{ }^{\circ} \mathrm{C}\right)$, until semen evaluation. Ejaculates only above $70 \%$ of the progressive motility were pooled.

Pooled sample was divided equally into four experimental groups and extended $(1: 1 \mathrm{v} / \mathrm{v})$ by rabbit semen extender supplemented with three levels of melatonin $\left(10^{-3} \mathrm{M}, 10^{-6} \mathrm{M}\right.$ and $\left.10^{-9} \mathrm{M}\right)$ or control (without melatonin). The semen diluent was composed from $250 \mathrm{mM}$ trishydroxymethyl- aminomethane, $83 \mathrm{mM}$ citric acid and $50 \mathrm{mM}$ glucose; supplemented with $3 \mathrm{M}$ dimethyl sulfoxide (Me2SO) and $0.1 \mathrm{M}$ sucrose as cry-protectants.

Extended semen of all groups was packed in French straws $0.25 \mathrm{ml}$ (IMV Technologies, France) and cooled at $5{ }^{\circ} \mathrm{C}$ for $2 \mathrm{~h}$. Cooled straws were suspended horizontally $5 \mathrm{~cm}$ over liquid nitrogen vapor for $15 \mathrm{~min}$ before being directly plunged into liquid nitrogen. Thawing was carried out by immersing the straws in a water bath at $45^{\circ} \mathrm{C}$ for 15 seconds. After thawing, sperm motility parameters and antioxidant biomarkers (malondialdehyde levels, MDA; total antioxidant capacity, TAC; catalase enzyme activity, CAT) were assayed for all treatment groups. In addition, the expression of mRNA stress-responserelated genes (nuclear factor erythroid 2like 2, NFE2L2; superoxide dismutase 1, SOD1) was analyzed in sperm for all treatment groups using the quantitative real-time PCR technique. Furthermore, a fertility trial was performed with thawed semen from each treatment group as mentioned below.

\section{Sperm motility}

An aliquot from each treatment group (10 $\mu \mathrm{l})$ was diluted 1:20 in Tris-citrateglucose extender and $10 \mu \mathrm{l}$ of the diluted sample was placed on a slide at $37^{\circ} \mathrm{C}$ for sperm motility analysis using a Computer Assisted Sperm Analysis (CASA; Sperm Vision $^{\mathrm{TM}}$ software minitube Hauptstraße 41. 84184 Tiefenbach, Germany). Ten microscopic fields were captured for each sample (2000 sperm). The motion characterization was recorded including distance curved line (DCL, $\mu \mathrm{m})$, distance average path (DAP, $\mu \mathrm{m}$ ), distance straight line (DSL, $\mu \mathrm{m})$, velocity curved line (VCL, $\mu \mathrm{m} / \mathrm{sec}$ ), velocity average path (VAP, $\mu \mathrm{m} / \mathrm{sec}$ ), velocity straight line (VSL, $\quad \mu \mathrm{m} / \mathrm{sec}$ ), linearity (LIN=VSL/VCL), $\quad$ straightness (STR=VSL/VAP), wobble (WOB=VAP/VCL), beat cross frequency $\left(\mathrm{BCF}, \mathrm{H}_{\mathrm{z}}\right)$ and amplitude of lateral head displacement (ALH, $\mu \mathrm{m}$ ).

\section{Antioxidant biomarkers assay}

Eight straws from each treatment group were thawed and diluted with $1 \mathrm{ml}$ of PBS buffer in 2-ml-eppendorf tubes. Samples were centrifuged at $1030 \times \mathrm{g}$ for $10 \mathrm{~min}$ at $4^{\circ} \mathrm{C}$. The precipitates were washed 3 times with PBS and collected by centrifugation at $1030 \times \mathrm{g}$ for $10 \mathrm{~min}$. After the third centrifugation, the sperm pellets were re-suspended with $1 \mathrm{ml}$ of deionized water, and then were snapfrozen and stored at $-80{ }^{\circ} \mathrm{C}$ until further biochemical analysis (Roca et al., 2005).

The samples were thawed, shook up, and centrifuged at $1030 \mathrm{xg}$ for $15 \mathrm{~min}$ at $4^{\circ} \mathrm{C}$. The supernatant was collected to determine the levels of MDA, TAC, and CAT activity, using colorimetric assay kits (MD-2529, TA-2513, CA-2517, respectively; Bio-Diagnostic, Inc., Egypt). The standard curves accuracy and 
sensitivity of the assay were performed following the kits' protocol, and the calculations were adjusted per mg protein for each assay. The total protein (TP) content was detected in the supernatant by the BCA protein assay kit (TP-2020; Bio-Diagnostic, Inc., Egypt) according to the manufacturer's protocol. The data were obtained for all analyses by using an automatic scanning spectrophotometer (CE1010, Cecil Instruments Limited, Cambridge, United Kingdom).

\section{Quantitative real-time PCR analysis}

Three replicates from the control and each melatonin group were used for RNA extraction using Direct-zol ${ }^{\mathrm{TM}}$ RNA MiniPrep (Zymo Research, U.S.A) according to manufacturer's instruction. The RNA quality and quantity were assessed using NanoDrop 2000c (Thermo Fisher Scientific Inc., USA). RNA was eluted in $11 \mu$ of elution buffer, and was reverse transcribed using $1 \mathrm{mM}$ oligo (dT) primers and Rever-AidcDNA synthesis kit (Thermo Fisher Scientific, Heidelberg, Germany) as per manufacturer's recommendations. Sequence-specific primers for the realtime PCR were designed using the Primer-blast web interface (http://www.ncbi.nlm.nih.gov/tools/prime r-blast/index.cgi) and each pair of primers was tested to achieve efficiencies close to 1 (Table 1). qRT-PCR analysis for two selected stress-related genes NFE2L2 and SOD1, and glyceraldehyde-3-phosphate dehydrogenase (GAPDH) as a housekeeping gene was performed in 20 $\mu \mathrm{l}$ reaction volume containing Maxima SYBR Green qPCR Master Mixes with ROX (Thermo Fisher Scientific, Heidelberg, Germany), the cDNA samples and the specific forward and reverse primers in $\mathrm{Mx} 3000 \mathrm{P}^{\mathrm{TM}}$ real time PCR system (Strata-gene).
The thermal cycling parameter was set to $95^{\circ} \mathrm{C}$ for $3 \mathrm{~min}, 40$ cycles at $95^{\circ} \mathrm{C}$ for $15 \mathrm{~s}$ and $60^{\circ} \mathrm{C}$ for $1 \mathrm{~min}$. After the end of the last cycle, melting curve was generated by starting the fluorescence acquisition at $60^{\circ} \mathrm{C}$ and taking measurements every $7 \mathrm{~s}$ interval until the temperature reached $95^{\circ} \mathrm{C}$. The comparative cycle threshold (CT) method was used to quantify fold changes $\left(2^{-} \Delta \Delta C T\right)$ in the relative gene expression of the target as described in a previous study (Livak and Schmittgen, 2001).

\section{Fertility trial}

A total of 20 multiparous New Zealand (NZW) rabbit does at 7-8 months of age (5 does for each treatment group) were selected for a fertility trial based on their reproductive status. (does with at least two successful and consecutive parities), and their receptivity at the time of insemination (does with red color of the vulvar lips). Each receptive doe was inseminated with pooled semen obtained from 2 straws after thawing, and immediately after insemination, was given an intramuscular injection of $\mathrm{GnRH}$ $(0.8 \mu \mathrm{g}$ of Buserelin acetate, Receptal, Egypt) for ovulation induction. Pregnancy diagnosis was checked by abdominal palpation at the $10^{\text {th }}$ day post insemination. The parturition data for each treatment group were recorded including the gestation period, the total born number, and the live born number and weight.

\section{Statistical Analysis}

Data were statistically analyzed according to Snedecor and Cochran (1982) using SAS software (SAS Institute Inc., 2011). One-way ANOVA was used to determine the effect of melatonin levels (Control, $10^{-9} \mathrm{M}, 10^{-6} \mathrm{M}$ and $10^{-3} \mathrm{M}$ ) on CASA parameters, antioxidant biomarkers and mRNA relative expressions, as well as, 
on the gestation period, the total born number, and the live born number and weight as the following fixed model:

$\mathrm{Y}_{\mathrm{ijk}}=\mu+\mathrm{Ti}+\mathrm{e}_{\mathrm{ijk}}$

Where: $\mathrm{Y}_{\mathrm{ijk}}=$ The observation; $\mu=$ Overall mean; $\mathrm{Ti}=$ Effect of treatments( $\mathrm{i}=1, \ldots 4) ; \mathrm{e}_{\mathrm{ijk}}=$ Random error component assumed to be normally distributed.

The pregnancy rate was analyzed using Chi-square test.

Duncan's multiple range tests was performed (Duncan, 1955) to detect significant differences among means.

\section{Sperm motility}

\section{RESULTS}

As shown in Table 2, the total and progressive motility of frozen/thawed sperm increased significantly $(\mathrm{P}<0.05)$ at $10^{-6} \mathrm{M}$ melatonin concentration when compared to the control group. Sperm velocity curved line (VCL) and velocity average path (VAP) traits were higher significantly $(\mathrm{P}<0.05)$ in melatonin groups of $10^{-9}$ and $10^{-6} \mathrm{M}$ than in the control group. The post-thaw sperm, velocity straight line (VSL) improved was significantly $(\mathrm{P}<0.05)$ by the addition of $10^{-9} \mathrm{M}$ melatonin to the freezing extender compared to the control. In contrast, the sperm STR and LIN were lower significantly $(\mathrm{P}<0.05)$ in melatonin groups of $10^{-9}$ and $10^{-6} \mathrm{M}$ than in the control group. On the other hand, the high concentration of melatonin up to $10^{-3} \mathrm{M}$ induced similar values or caused to decrease significant $(\mathrm{P}<0.05)$ in most motility parameters as compared to the control group.

\section{Antioxidant biomarkers analysis}

The effect of melatonin on the levels of MDA and TAC, as well as, CAT activity in frozen-thawed semen is shown in Table 3. Melatonin supplementation to freezing extenders at $10^{-9} \mathrm{M}$ and $10^{-6} \mathrm{M}$ decreased significantly $(\mathrm{P}<0.05) \mathrm{MDA}$ by 48.8 and $51.1 \%$, respectively, when compared to the control.

In contrast, the concentration of $10^{-6} \mathrm{M}$ melatonin significantly $(\mathrm{P}<0.05)$ elevated TAC by 2.2 -fold compared to the control group. Furthermore, CAT activity in sperm supplemented with $10^{-9}$ $\mathrm{M}$ and $10^{-6} \mathrm{M}$ melatonin was significantly $(\mathrm{P}<0.05)$ increased by 30.7 and $38.4 \%$ when compared to the control group, respectively.

\section{Quantitative real-time PCR analysis}

The mRNA relative expression of NFE2L2 and SOD1 genes in control and melatonin groups are illustrated in Figure 1. An increase in NFE2L2 relative expression was found in sperm groups treated with $10^{-6} \mathrm{M}$ and $10^{-3} \mathrm{M}$ of melatonin (14.8 and 10.3-fold, respectively) as compared to the control group. Also, sperms supplemented with melatonin showed a high relative expression of SOD1 gene (2.0-3.8 fold) when compared to the control group. However, These differences were not statistically significant.

\section{Fertility traits}

The fertility traits after insemination with frozen semen supplemented with different levels of melatonin are shown in Table 4. It was observed that the pregnancy rate tended to increase by supplementation of melatonin to frozen semen at $10^{-6} \mathrm{M}$ (95\%) when compared to both $10^{-9} \mathrm{M}$ and control groups (80\%), while it tended to dramatically $(\mathrm{P}<0.05)$ decrease at higher levels of melatonin up to $10^{-3} \mathrm{M}$ melatonin $(60 \%)$. Furthermore, total born and live born traits were higher significantly $(\mathrm{P}<0.05)$ in rabbit does inseminated with frozen semen of $10^{-9} \mathrm{M}$ and $10^{-6} \mathrm{M}$ groups than $10^{-3} \mathrm{M}$ and control groups. In contrast, a significant $(\mathrm{P}<0.05)$ decrease was observed in the average weight of live born per doe in the 
SH M. Dessouki ${ }^{1,2^{* *}}$ and O. G. Sakr ${ }^{1}$

$10^{-9} \mathrm{M}$ and $10^{-6} \mathrm{M}$ treatment groups as compared to the $10^{-3} \mathrm{M}$ and control groups(Table 4).

\section{DISCUSSION}

It is well known that semen freezing is an essential technique for routine artificial insemination and genetic preservation programs in rabbit species (Mocé and Vicente, 2009; Viudes-De-Castro et al., 2014). Among the limiting factors that affect the fertility of frozen semen after thawing are the excessive production of ROS and free radicals in freezing extenders during the cryopreservation process (Benson et al., 2012). Recently, melatonin has been used as an antioxidant to minimize the negative effects of oxidative stress on mammalian sperm characteristics and functions (Ashrafi et al., 2013; Casao et al., 2010). In the current research, the rabbit was used as a particular animal model to study the capability of melatonin supplementation to freezing extenders to maintain sperm fertility after thawing, focusing on sperm motility, antioxidant biomarkers, and stress-responserelated genes.

The results indicate a positive effect of melatonin at moderate levels $\left(10^{-6}\right.$ and $10^{-9}$ M) on fertility traits of rabbits. The increased fertility and prolificacy of spermatozoa could be attributed to the improvement of sperm motility (Farrell et al., 1998). It was noticed from CASA analysis that the addition of melatonin at $10^{-6} \mathrm{M}$ and $10^{-9} \mathrm{M}$ to the freezing extender increased the progressive motility, curvilinear and path velocity, ALH, and BCF parameters of rabbit sperm. These results are in agreement with previous works in ram (Succu et al., 2011), in bovine (Ashrafi et al., 2013) and in mouse (Chen et al., 2016). In contrast, the straightness and linearity of sperm in melatonin groups were lower compared to the control group, in the present study. A previous work (Viudes-DeCastro et al., 2005), also demonstrated that some sperm parameters like LIN \% did not change in the same manner of other motility parameters during rabbit semen freezing.
On the contrary, others claimed that melatonin didn't improve sperm motility parameters (Balao da Silva et al., 2011; Kaya et al., 2001). These controversial results indicate that melatonin effect may differ based on many factors such as species, melatonin concentration, extender components, and the cryopreservation protocol itself (Chen et al., 2016; Viudes-DeCastro et al., 2014).

Indeed, the potent antioxidant capacity of melatonin is well established because it acts through several mechanisms (Reiter et al., 2009). sperm membranes contain high amount of polyunsaturated fatty acids (PUFA) (Apel-Paz et al., 2003), and the endogenous antioxidant defense systems within the spermatozoa decrease by the process of dilution and cryopreservation (Alvarez and Storey, 1992; Bilodeau et al., 2000). These factors make sperm very sensitive and vulnerable to the attack of free radicals and initiation of LPO cascades (Bansal and Bilaspuri, 2011). In addition, over-production of ROS and free radicals induced during freeze-thawed semen process has harmful effects on sperm quality (Maia et al., 2010; Zhao et al., 2015). MDA, an oxidizing agent, was measured to determine the oxidative stress and LPO in various cell types (Urso and Clarkson, 2003). In our experimental model, melatonin supplementation to semen samples at a concentration of $10^{-9} \mathrm{M}$ and $10^{-6} \mathrm{M}$ reduced MDA level and stimulate the activity of CAT in sperm cells after freeze-thawing. This result is in agreement with Franco and Markus, (2014) who showed the ability of melatonin to enhance the activity of CAT and reduced MDA concentration and clarify the ability of melatonin molecule to protect CAT and MDA from the ROS. Furthermore, melatonin has also been confirmed to modulate the activities of enzymes that stimulate the total antioxidative defense capacity (Bharti et al., 2011). Even though both concentration of melatonin, $10^{-9} \mathrm{M}$ and $10^{-6} \mathrm{M}$, were able to stimulate the activity of CAT and reduce MDA level, only one 
concentration, $10^{-6} \mathrm{M}$, was able to increase TAC level (Table 3). The current result could be due to the higher concentration of melatonin that acts as a better direct scavenger of free radicals (Reiter et al., 2003), and as stimulator of enzymes involved in the antioxidant defense (Ashrafi et al., 2013). However, the high level of melatonin $\left(10^{-3} \mathrm{M}\right)$ had no effect on antioxidant biomarkers, compared to the control. It could be due to the negative effects of the pharmacological dose of melatonin on sperm (Succu et al., 2011).

The present study also investigated if there are further effects for melatonin supplementation to semen extender on the expression of oxidative-stress-responserelated genes NFE2L2 and SOD1. Our results demonstrate that melatonin increased the levels of mRNA for NFE2L2 and SOD1 in rabbit sperm. This result is in accordance with our previously published data in rabbit embryos (Mehaisen et al., 2015). It was reported before that NFE2L2 plays as an oxidative stress regulator through switching the endogenous antioxidant target genes like SOD1 (Kensler et al., 2007; Nakabeppu et al., 2007). As compared to the control, an elevation in NFE2L2 and SOD1 expressions was observed when melatonin added to semen extenders at $10^{-6}$ and $10^{-3} \mathrm{M}$ concentrations. However, motility, antioxidant biomarkers and fertility measurements seem to be consistent with molecular results at only $10^{-6} \mathrm{M}$ concentration, but not at the higher concentration of melatonin at $10^{-3} \mathrm{M}$. The abundance of melatonin $\left(10^{-3} \mathrm{M}\right)$ in semen extenders could trigger the expression of NFE2L2 and SOD1 genes in sperm under the exposure to oxidative stress during cryopreservation (Gad et al., 2012). While the absence or adverse effect of $10^{-3} \mathrm{M}$ melatonin on motility and other parameters could be due to depletion of all ROS, including those essential for the sperm cell physiology (Cruz et al., 2014). Other studies indicated that protective effects of melatonin on cryopreservation injuries occurs in a dose- dependent manner (Ashrafi et al., 2013; Succu et al., 2011). Moreover, extreme doses of antioxidants in the freezing medium can impede the normal ROS-associated functions of spermatozoa (Roca et al., 2004).

\section{CONCLUSIONS}

The fertilizing ability of frozen rabbit semen could be improved at the level of motion characteristics (sperm motility and velocities) when samples were supplemented with $10^{-6}$ $\mathrm{M}$ melatonin. The antioxidant capacity of melatonin overcomes free radicals formed during freezing process by increasing TAC and CAT, and reducing MDA activity. Therefore, the addition of melatonin to semen freezing extenders could be recommended as an efficient application in artificial insemination and in vitro fertilization with cryopreserved rabbit sperm.

\section{ACKNOWLEDGMENTS}

This study was supported by funds assigned to scientific research affairs at the Faculty of Agriculture, Cairo University, Egypt . All facilities and instruments used in this experiment were provided from the Rabbit Embryo Cryobank Project (RECP) laboratory, and the Artificial Insemination and Ultrasonic Unit, Department of Animal Production, Faculty of Agriculture, Cairo University, Egypt. We would like to thank Prof. Dr. Gamal M. K. Mehaisen, Department of Animal Production, Faculty of Agriculture, Cairo University, for his technical support during the study and for his revision of the manuscript 
Table (1): Details of primers used for real-time PCR quantitative analysis.

\begin{tabular}{|c|c|c|c|c|c|}
\hline $\begin{array}{c}\text { Gene } \\
\text { symbol }\end{array}$ & $\begin{array}{l}\text { Gene full } \\
\text { name }\end{array}$ & $\begin{array}{c}\text { Gen bank accession } \\
\text { number }\end{array}$ & Primer sequences & $\begin{array}{c}\text { Annealing } \\
\text { temperature } \\
\left({ }^{\circ} \mathrm{C}\right)\end{array}$ & $\begin{array}{c}\text { Product size } \\
\text { (bp) }\end{array}$ \\
\hline NFE2L2 & $\begin{array}{c}\text { Nuclear Factor } \\
\text { Erythroid 2-Like } 2\end{array}$ & XM_002712305 & $\begin{array}{l}\text { F:tgaaatcctcccaattcag } \\
\text { R·gtgaagactoggctctcoac }\end{array}$ & 55 & 228 \\
\hline SOD1 & $\begin{array}{l}\text { Superoxide Dismutase } \\
1\end{array}$ & NM_001082627 & $\begin{array}{l}\text { F:cacttcgagcagaagggaac } \\
\text { R:cgtgcctctcttcatccttc }\end{array}$ & 54 & 184 \\
\hline GAPDH & $\begin{array}{l}\text { Glyceraldehyde-3- } \\
\text { Phosphate } \\
\text { Dehydrogenase }\end{array}$ & NM_001082253 & F:aggtcatccacgaccacttc & 57 & 202 \\
\hline & & & R:gtgagtttcccgttcagctc & & \\
\hline
\end{tabular}

F:Forward, R: Reverse XM and NM: Gen bank accession number 
Table (2):Sperm motility traits (LSM \pm SE) of frozen rabbit semen supplemented with different levels of melatonin.

\begin{tabular}{|c|c|c|c|c|c|}
\hline \multirow{2}{*}{ Parameters } & \multicolumn{4}{|c|}{ Experimental groups (different levels of melatonin, $M$ ) } & \multirow{2}{*}{$\begin{array}{l}\text { Sig. } \\
\text { test }\end{array}$} \\
\hline & Control & $10^{-9} \mathrm{M}$ & $10^{-6} \mathrm{M}$ & $10^{-3} \mathrm{M}$ & \\
\hline Total motility (\%) & $66.1 \pm 1.1^{\mathrm{b}}$ & $67.8 \pm 0.9^{b}$ & $75.5 \pm 1.1^{\mathrm{a}}$ & $61.6 \pm 1.0^{\mathrm{c}}$ & 0.0001 \\
\hline Progressive motility (\%) & $41.9 \pm 1.1^{\mathrm{c}}$ & $46.6 \pm 0.8^{b}$ & $52.8 \pm 1.1^{\mathrm{a}}$ & $38.2 \pm 0.9^{\mathrm{d}}$ & 0.0001 \\
\hline $\mathrm{VAP}(\mu \mathrm{m} / \mathrm{s})$ & $44.8 \pm 1.1^{\mathrm{b}}$ & $50.7 \pm 0.8^{\mathrm{a}}$ & $48.8 \pm 1.0^{\mathrm{a}}$ & $44.7 \pm 0.9^{b}$ & 0.0001 \\
\hline $\operatorname{VCL}(\mu \mathrm{m} / \mathrm{s})$ & $82.4 \pm 2.5^{\mathrm{c}}$ & $101.4 \pm 1.9^{\mathrm{a}}$ & $90.8 \pm 2.4^{b}$ & $88.6 \pm 2.2^{c}$ & 0.0001 \\
\hline $\operatorname{VSL}(\mu \mathrm{m} / \mathrm{s})$ & $32.5 \pm 0.6^{\mathrm{bc}}$ & $34.7 \pm 0.5^{\text {a }}$ & $33.9 \pm 0.6^{\mathrm{ab}}$ & $32.2 \pm 0.5^{\mathrm{c}}$ & 0.0033 \\
\hline STR $(\%)$ & $72.2 \pm 0.0^{\mathrm{a}}$ & $68.1 \pm 0.0^{b}$ & $68.9 \pm 0.0^{b}$ & $71.5 \pm 0.0^{\mathrm{a}}$ & 0.0001 \\
\hline LIN (\%) & $39.3 \pm 0.0^{\mathrm{a}}$ & $33.8 \pm 0.0^{\mathrm{c}}$ & $36.9 \pm 0.0^{\mathrm{b}}$ & $39.8 \pm 0.0^{\mathrm{a}}$ & 0.0001 \\
\hline WOB (VAP/VCL) & $0.542 \pm 0.0^{\mathrm{a}}$ & $0.495 \pm 0.0^{b}$ & $0.535 \pm 0.0^{\mathrm{a}}$ & $0.551 \pm 0.0^{\mathrm{a}}$ & 0.0001 \\
\hline $\mathrm{ALH}(\mu \mathrm{m})$ & $5.1 \pm 0.1^{b}$ & $5.5 \pm 0.1^{\mathrm{a}}$ & $5.6 \pm 0.1^{a}$ & $5.2 \pm 0.1^{b}$ & 0.0004 \\
\hline $\mathrm{BCF}(\mathrm{Hz})$ & $18.1 \pm 0.3^{b c}$ & $20.1 \pm 0.2^{\mathrm{a}}$ & $18.8 \pm 0.3^{b}$ & $17.9 \pm 0.2^{c}$ & 0.0001 \\
\hline
\end{tabular}

a,b,c,d Means having different superscripts within the same row differ significantly $(\mathrm{P}<0.05)$

i DCL: Distance Curved Line $(\mu \mathrm{m})$; DAP: Distance Average Path $(\mu \mathrm{m})$; DSL: Distance Straight Line $(\mu \mathrm{m})$; VCL: Velocity Curved Line $(\mu \mathrm{m} / \mathrm{s})$; VAP: Average path velocity $(\mu \mathrm{m} / \mathrm{s})$; VSL: Velocity Straight Line $(\mu \mathrm{m} / \mathrm{s})$; LIN: Linearity (VSL/VCL); STR: Straightness (VSL/VAP); WOB: Wobble

Table (3): Antioxidant biomarkers (mean \pm SE) of post freezing rabbit spermatozoa as affected by different levels of melatonin.

\begin{tabular}{|c|c|c|c|c|c|}
\hline \multirow{2}{*}{ Parameters } & \multicolumn{4}{|c|}{ Experimental groups (different levels of melatonin, $M$ ) } & \multirow{2}{*}{ test } \\
\hline & Control & $10^{-9} \mathrm{M}$ & $10^{-6} \mathrm{M}$ & $10^{-3} \mathrm{M}$ & \\
\hline ng protein) & $0.45 \pm 0.074^{\mathrm{a}}$ & $0.23 \pm 0.020^{b}$ & $0.22 \pm 0.009^{b}$ & $0.40 \pm 0.050^{\mathrm{a}}$ & 0.002 \\
\hline $\mathrm{TAC}(\mu \mathrm{M} / \mathrm{mg}$ protein $)$ & $0.05 \pm 0.008^{b}$ & $0.04 \pm 0.003^{b}$ & $0.11 \pm 0.015^{\mathrm{a}}$ & $0.05 \pm 0.005^{b}$ & 0.0001 \\
\hline CAT (U/mg protein) & $0.13 \pm 0.018^{b}$ & $0.17 \pm 0.003^{\mathrm{a}}$ & $0.18 \pm 0.012^{\mathrm{a}}$ & $0.12 \pm 0.013^{b}$ & 0.005 \\
\hline
\end{tabular}

a,b Means having different superscripts within the same row differ significantly $(\mathrm{P}<0.05)$

$\mathrm{MDA}=$ Lipid peroxidation; $\mathrm{CAT}=$ Catalase $\mathrm{TAC}=$ Total antioxidant capacity 
Table (4): Fertility traits (LSM \pm SE) of frozen rabbit semen supplemented with different levels of melatonin.

\begin{tabular}{|c|c|c|c|c|c|}
\hline \multirow[b]{2}{*}{ Parameters } & \multicolumn{4}{|c|}{ Experimental groups (different levels of melatonin, $\mathrm{M}$ ) } & \multirow{2}{*}{$\begin{array}{l}\text { Sig. } \\
\text { test }\end{array}$} \\
\hline & Control & $1^{-9} \mathrm{M}$ & $10^{-6} \mathrm{M}$ & $10^{-3} \mathrm{M}$ & \\
\hline $\begin{array}{l}\text { No. inseminated does } \\
\text { Pregnancy rate }^{1} \\
\text { Total born } \\
\text { Live born } \\
\text { Live born weight } \\
\text { L }^{4}(\mathrm{~g})\end{array}$ & $\begin{array}{c}5 \\
0.80 \pm 0.092^{\mathrm{ab}} \\
3.8 \pm 0.38^{\mathrm{b}} \\
2.8 \pm 0.21^{\mathrm{b}} \\
64.2 \pm 1.79^{\mathrm{a}} \\
\end{array}$ & $\begin{array}{c}5 \\
0.80 \pm 0.092^{\mathrm{ab}} \\
7.8 \pm 0.35^{\mathrm{a}} \\
7.7 \pm 0.38^{\mathrm{a}} \\
52.7 \pm 0.87^{\mathrm{b}} \\
\end{array}$ & $\begin{array}{c}5 \\
0.95 \pm 0.050^{\mathrm{a}} \\
8.3 \pm 0.68^{\mathrm{a}} \\
6.6 \pm 0.61^{\mathrm{a}} \\
48.1 \pm 1.80^{\mathrm{b}} \\
\end{array}$ & $\begin{array}{c}5 \\
0.60 \pm 0.112^{\mathrm{b}} \\
4.0 \pm 0.65^{\mathrm{b}} \\
3.7 \pm 0.51^{\mathrm{b}} \\
62.8 \pm 2.60^{\mathrm{a}} \\
\end{array}$ & 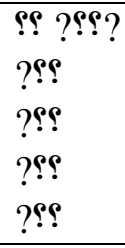 \\
\hline
\end{tabular}

${ }^{a, b}$ Means having different superscripts within the same row differ significantly $(\mathrm{P}<0.05)$

${ }^{1}$ Pregnancy rate $=$ No. positive palpations $/$ no. inseminations $(\%)$

${ }^{3}$ Calculated as average number per doe

空 Calculated as average weight of live born per doe 


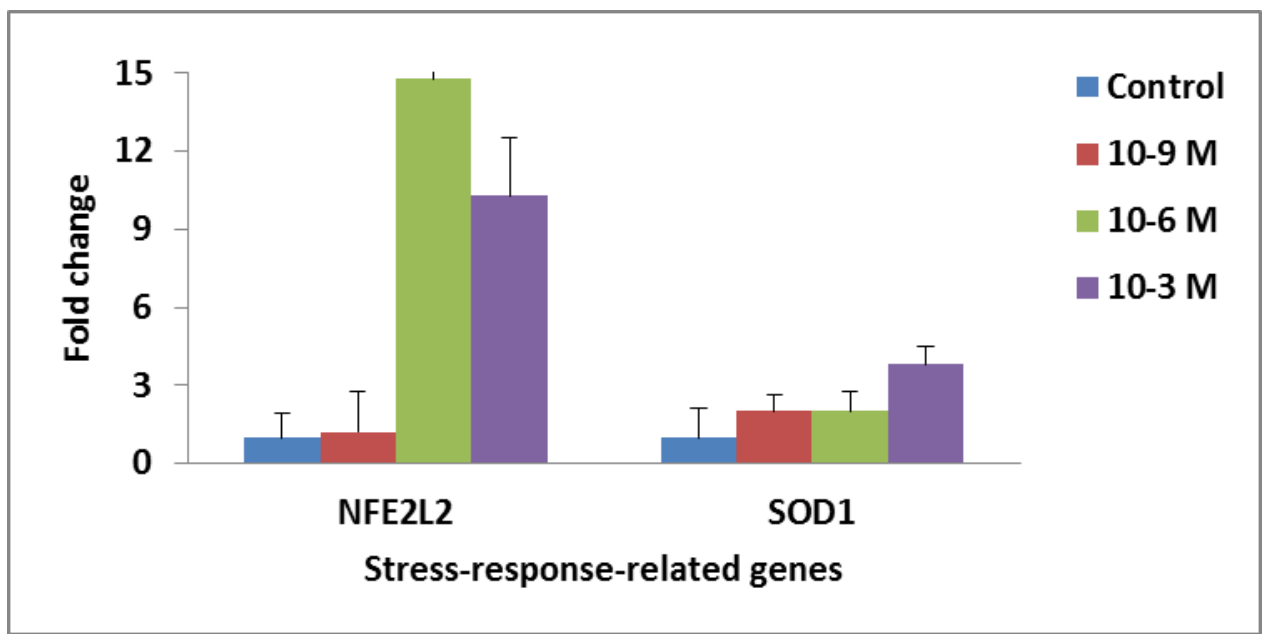

Figure (1): Expression of some oxidative-stress-response related genes (NFE2L2 and SOD1) in frozen rabbit sperm diluted with $(1: 1 \mathrm{v} / \mathrm{v})$ semen extender supplemented with different levels of melatonin $\left(10^{-9} \mathrm{M}, 10^{-6} \mathrm{M}\right.$ and $\left.10^{-3} \mathrm{M}\right)$ or without melatonin as control. Bars express the least squared means $(\mathrm{LSM}) \pm$ standard error $(\mathrm{SE})(\mathrm{n}=3)$. No significant differences were observed among groups at $\mathrm{P}<0.05$. 
SH M. Dessouki ${ }^{1,2 *}$ and O. G. Sakr ${ }^{1}$

\section{REFERENCES}

Alvarez, J.G. and Storey, B.T. 1992. Evidence for increased lipid peroxidative damage and loss of superoxide dismutase activity as a mode of sublethal cryodamage to human sperm during cryopreservation. J. Androl. 13, 232-41.

Apel-Paz, M.; Vanderlick, T.K.; Chandra, N. and Doncel, G.F. 2003. A hierarchy of lipid constructs for the sperm plasma membrane. Biochem. Biophys. Res. Commun. 309, 724-32.

Ashrafi, I.; Kohram, H.; Naijian, H.; Bahereini, M. and Poorhamdollah, M. 2011. Protective effect of melatonin on sperm motility parameters on liquid storage of ram semen at $5^{\circ} \mathrm{C}$. African J. Biotechnol. $10,6670-6674$.

Ashrafi, I.; Kohram, H. and TayefiNasrabadi, H. 2013. Antioxidant effects of bovine serum albumin on kinetics, microscopic and oxidative characters of cryopreserved bull spermatozoa. Spanish J. Agric. Res. 11, 695-701.

Awad, H.; Halawa, F.; Mostafa, T. and Atta, H. 2006. Melatonin hormone profile in infertile males. Int. J. Androl. 29, 409-413.

Balao da Silva, C.M.; Macías-García, B.; Miró-Morán, A.; GonzálezFernández, L.; Morillo-Rodriguez, A.; Ortega-Ferrusola, C.; GallardoBolaños, J.M.; Stilwell, G.; Tapia, J.A. and Peña, F.J. 2011. Melatonin reduces lipid peroxidation and apoptotic-like changes in stallion spermatozoa. J. Pineal Res. 51, 172179.

Bansal, A.K. and Bilaspuri, G.S. 2011. Impacts of Oxidative Stress and Antioxidants on Semen Functions. Vet. Med. Int. 2011, 1-7.
Benson, J.D.; Woods, E.J.; Walters, E.M. and Critser, J.K. 2012. The cryobiology of spermatozoa. Theriogenology 78, 1682-1699.

Berra, B. and Rizzo, A.M. 2009. Melatonin: circadian rhythm regulator, chronobiotic, antioxidant and beyond. Clin. Dermatol. 27, 202-209.

Bharti, V.K.; Srivastava, R.S.; Subramaian, P.; Warren Spence, D.; Pandi-Perumal, S.R. and Brown, G.M. 2011. Cerebral epiphyseal proteins and melatonin modulate the hepatic and renal antioxidant defense of rats. Int. J. Nephrol. 2011, 142896.

Bilodeau, J.F.; Chatterjee, S.; Sirard, M.A. and Gagnon, C. 2000. Levels of antioxidant defenses are decreased in bovine spermatozoa after a cycle of freezing and thawing. Mol. Reprod. Dev. 55, 282-288.

Casao, A.; Abecia, J.A.; Cebrián-Pérez, J.; Muiño-Blanco, T.; Vázquez, M.I. and Forcada, F. 2010. The effects of melatonin on in vitro oocyte competence. Spanish J. Agric. Res. 2010 8, 35-41.

Chen, X. jiao; Zhang, Y.; Jia, G. xue; Meng, Q. gang; Bunch, T.D.; Liu, G. shi; Zhu, S. en and Zhou, G. bin. 2016. Effect of melatonin supplementation on cryopreserved sperm quality in mouse. Cryo-Letters 37, 115-122.

Cruz, M.H.C.; Leal, C.L.V.; da Cruz, J.F.; Tan, D.-X. and Reiter, R.J. 2014. Role of melatonin on production and preservation of gametes and embryos: a brief review. Anim. Reprod. Sci. 145, 150-160.

El-Sokkary, G.H.; Kamel, E.S. and Reiter, R.J. 2003. Prophylactic effect of melatonin in reducing lead-induced neurotoxicity in the rat. Cell. Mol. Biol. Lett. 8, 461-70. 
Melatonin concentrations-sperm motility-fertility traits; bucks \& does-rabbits

Duncan, D. B. 1955. Multiple Ranges and Multiple F Test. Biometrics, 11: 1-42.

Farrell, P.B.; Presicce, G.A.; Brockett, C.C. and Foote, R.H. 1998. Quantification of bull sperm characteristics measured by computerassisted sperm analysis (CASA) and the relationship to fertility. Theriogenology 49, 871-879.

Franco, D.G. and Markus, R.P. 2014. The Cellular State Determines the Effect of Melatonin on the Survival of Mixed Cerebellar Cell Culture. PLoS One 9, e106332.

Gad, A.; Hoelker, M.; Besenfelder, U.; Havlicek, V.; Cinar, U.; Rings, F.; Held, E.; Dufort, I.; Sirard, M.; Schellander, K. and Tesfaye, D. 2012. Molecular Mechanisms and Pathways Involved in Bovine Embryonic Genome Activation and Their Regulation by Alternative In Vivo and In Vitro Culture Conditions. Biol. Reprod. 87, 100-100.

Gil-Guzman, E.; Ollero, M.; Lopez, M.C.; Sharma, R.K.; Alvarez, J.G.; Thomas, A.J. and Agarwal, A. 2001. Differential production of reactive oxygen species by subsets of human spermatozoa at different stages of maturation. Hum. Reprod. 16, 19221930.http://www.ncbi.nlm.nih.gov/tool s/primer-blast/index.cgi see page 6

Jang, H.Y.; Kim, Y.H.; Kim, B.W.; Park, I.C.; Cheong, H.T.; Kim, J.T. Park, C.K.; Kong, H.S.; Lee, H.K. and, Yang, B.K. 2010. Ameliorative effects of melatonin against hydrogen peroxide-induced oxidative stress on boar sperm characteristics and subsequent in vitro embryo development. Reprod. Domest. Anim. 45, 943-950.

Kadirvel, G.; Kumar, S. and Kumaresan, A. 2009. Lipid peroxidation, mitochondrial membrane potential and DNA integrity of spermatozoa in relation to intracellular reactive oxygen species in liquid and frozen-thawed buffalo semen. Anim. Reprod. Sci. 114, 125-134.

Karimfar, M.H.; Niazvand, F.; Haghani, K.; Ghafourian, S.; Shirazi, R. and Bakhtiyari, S. 2015. The protective effects of melatonin against cryopreservation-induced oxidative stress in human sperm. Int. J. Immunopathol. Pharmacol. 28, 69-76.

Kaya, A.; Aksoy, M.; Baspinar, N.; Yildiz, C. and Ataman, M.B. 2001. Effect of melatonin implantation to sperm donor rams on post-thaw viability and acrosomal integrity of sperm cells in the breeding and nonbreeding season. Reprod. Domest. Anim. 36, 211-5.

Kensler, T.W.; Wakabayashi, N. and Biswal, S. 2007. Cell Survival Responses to Environmental Stresses Via the Keap1-Nrf2-ARE Pathway. Annu. Rev. Pharmacol. Toxicol. 47, 89-116.

Khalil, M.H., 2002. The Baladi Rabbits (Egypt)., in: Khalil M. H., Baselga M. (Eds.), Rabbit Genetic Resources in Mediterranean Countries. CIHEAM, Zaragoza, p. 41-50 (Options Méditerranéennes : Série B, 38).

Kumaresan, A.; Kadirvel, G.; Bujarbaruah, K.M.; Bardoloi, R.K.; Das, A.; Kumar, S. and Naskar, S. 2009. Preservation of boar semen at $18^{\circ} \mathrm{C}$ induces lipid peroxidation and apoptosis like changes in spermatozoa. Anim. Reprod. Sci. 110, 162-171.

Lançoni, R.; Celeghini, E.C.C.; Alves, M.B.R.; Lemes, K.M. GonellaDiaza, A.M. Oliveira, L.Z. and Arruda, R.P. de. 2018. Melatonin Added to Cryopreservation Extenders 
SH M. Dessouki ${ }^{1,2^{*}}$ and O. G. Sakr ${ }^{1}$

Improves the Mitochondrial

Membrane Potential of Postthawed Equine Sperm. J. Equine Vet. Sci. 69, 78-83.

Li, Y.; Huang, Y.; Piao, Y.; Nagaoka, K.; Watanabe, G. and Taya, K., Li, C. 2013. Protective effects of nuclear factor erythroid 2-related factor 2 on whole body heat stress-induced oxidative damage in the mouse testis. Reprod. Biol. Endocrinol. 11, 23.

Livak, K.J. and Schmittgen, T.D. 2001. Analysis of Relative Gene Expression Data Using Real-Time Quantitative PCR and the 2- $\Delta \Delta C T$ Method. Methods 25, 402-408.

Lucio, C.F.; Regazzi, F.M.; Silva, L.C.G.; Angrimani, D.S.R.; Nichi, M. and Vannucchi, C.I. 2016. Oxidative stress at different stages of two-step semen cryopreservation procedures in dogs. Theriogenology $85,1568-1575$.

Maia, M. da S.; Bicudo, S.D.; Sicherle, C.C.; Rodello, L. and Gallego, I.C.S. 2010. Lipid peroxidation and generation of hydrogen peroxide in frozen-thawed ram semen cryopreserved in extenders with antioxidants. Anim. Reprod. Sci. 122, 118-123.

Mehaisen, G.M.K.; Saeed, A.M.; Gad, A.; Abass, A.O.; Arafa, M.; ElSayed, A. and Fraidenraich, D. 2015. Antioxidant Capacity of Melatonin on Preimplantation Development of Fresh and Vitrified Rabbit Embryos: Morphological and Molecular Aspects. PLoS One 10, e0139814.

https://doi.org/10.1371/journal.pone.0 139814

Mocé, E. and Vicente, J.S. 2009. Rabbit sperm cryopreservation: A review. Anim. Reprod. Sci. 110, 1-24.
Nakabeppu, Y.; $\quad$ Tsuchimoto, D.; Yamaguchi, $H$. and Sakumi, $K$. 2007. Oxidative damage in nucleic acids and Parkinson's disease. J. Neurosci. Res. 85, 919-934.

NRC 1977. National Research Council: Nutrient Requirements of Rabbits. 2nd Revised Edition, National Academy of Sciences, Washington, DC. USA.

Partyka, A.; Lukaszewicz, E.; Niżański, W. and Nizański, W. 2012. Effect of cryopreservation on sperm parameters, lipid peroxidation and antioxidant enzymes activity in fowl semen. Theriogenology 77, 14971504.

Reiter, R.J.; Paredes, S.D.; Manchester, L.C.and Tan, D.X. 2009. Reducing oxidative/nitrosative stress: a newly-discovered genre for melatonin. Crit. Rev. Biochem. Mol. Biol. 44, 175-200.

Reiter, R.J.; Tan, D.X.; Mayo, J.C.; Sainz, R.M.; Leon, J. and Czarnocki, Z. 2003. Melatonin as an antioxidant: biochemical mechanisms and pathophysiological implications in humans. Acta Biochim. Pol. 50, 112946.

Roca, J.; Gil, M.A.; Hernandez, M.; Parrilla, I.; Vazquez, J.M. and Martinez, E.A. 2004. Survival and Fertility of Boar Spermatozoa after Freeze-Thawing in Extender Supplemented with Butylated Hydroxytoluene. J. Androl. 25, 397405.

Roca, J.; Rodríguez, M.J.; Gil, M.A.; Carvajal, G.; Garcia, E.M.; Cuello, C.; Vazquez, J.M. and Martinez, E.A. 2005. Survival and in vitro fertility of boar spermatozoa frozen in the presence of superoxide dismutase and/or catalase. J. Androl. 26, 15-24.

Sarıözkan, S.; Tuncer, P.B.; 
Melatonin concentrations-sperm motility-fertility traits; bucks \& does-rabbits

Büyükleblebici, S.; Bucak, M.N.; Cantürk, F. and Eken, A. 2015. Antioxidative effects of cysteamine, hyaluronan and fetuin on post-thaw semen quality, DNA integrity and oxidative stress parameters in the Brown Swiss bull. Andrologia 47, 138-147.

SAS Institute Inc. 2011. SAS/STAT® 9.3 User's Guide. SAS Inst. Inc., Cary, NC, USA.

Sendcor, G. W. and Cochran, W. G. 1982. Statistical Methods $2^{\text {nd }}$ Edition. Lowa University., press. Ames., Iowa, USA.

Succu, S.; Berlinguer, F.; Pasciu, V.; Satta, V.; Leoni, G.G. and Naitana, S. 2011. Melatonin protects ram spermatozoa from cryopreservation injuries in a dose-dependent manner. J. Pineal Res. 50, 310-318.

Tan, D.; Reiter, R.J.; Manchester, L.C.; Yan, M.; El-Sawi, M.; Sainz, R.M.; Mayo, J.C.; Kohen, R.; Allegra, M.; Hardeland, R. and Hardelan, R. 2002. Chemical and Physical Properties and Potential Mechanisms: Melatonin as a Broad Spectrum Antioxidant and Free Radical Scavenger. Curr. Top. Med. Chem. 2, 181-197.
Urso, M.L. and Clarkson, P.M. 2003.

Oxidative stress, exercise, and antioxidant supplementation. Toxicology 189, 41-54.

Viudes-De-Castro, M.P.; Lavara, R.; Safaa, H.M.; Marco-Jiménez, F.; Mehaisen, G.M.K. and Vicente, J.S. 2014. Effect of freezing extender composition and male line on semen traits and reproductive performance in rabbits. Animal 8, 765-770.

Viudes-De-Castro, M.P.; Mocé, E.; Vicente, J.S.; Marco-Jiménez, F. and Lavara, R. 2005. In vitro evaluation of in vivo fertilizing ability of frozen rabbit semen. Reprod. Domest. Anim. 40, 136-140.

Zhao, X.L.; Li, Y.K.; Cao, S.J.; Hu, J.H.; Wang, W.H.; Hao, R.J.; Gui, L.S. and Zan, L.S. 2015. Protective effects of ascorbic acid and vitamin $\mathrm{E}$ on antioxidant enzyme activity of freeze-thawed semen of Qinchuan bulls. Genet. Mol. Res. 14, 25722581 . 


\title{
تأثير إضافة الميلاتونين لمخفف التجميد على حركة الميوانات المنوية، مضادات الأكسدة والقدرة الإخصابية فى الأرانب
}

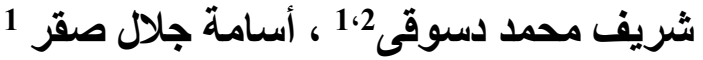

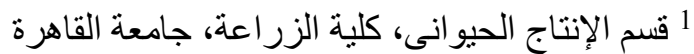 \\ 20 مجمع المعامل البحثية ، كلية الزراعة، الزراعة، جامعة القاهرة القاهة
}

أجريت هذه الدراسة لقياس القدرة الإخصابية للسائل المنوى المجمد للأر انب فى وجود الميلاتونين كمضاد للأكسدة.

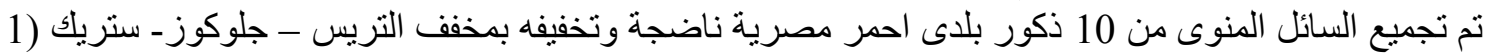

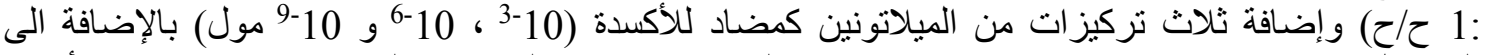
الكنترول وتم تجميده فى درجة -196 مئوية. بعد الإسالة تم تقييم حركة الحيو انات المنوية، قدرة مضادات الأكسدة و القدرة الإخصابية.

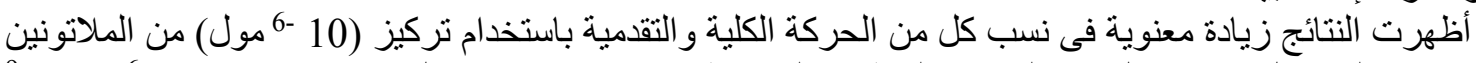

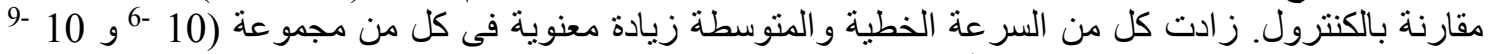

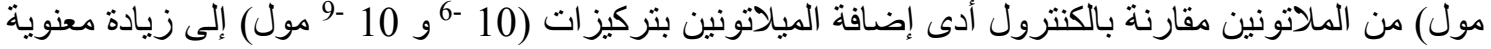

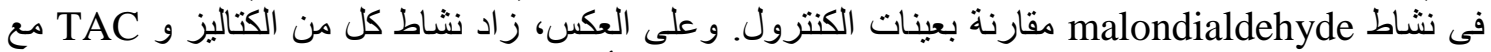

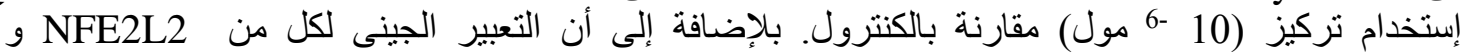

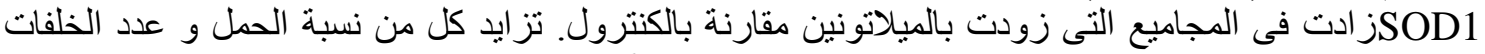

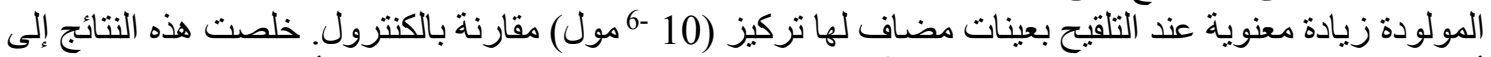

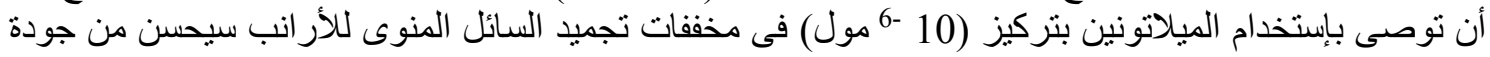
السائل المنوى و القدرة الإخصابية بعد الإسالة. 